

\title{
First fossil of the extant flat wasp genus Dissomphalus Ashmead, 1893 (Hymenoptera: Bethylidae: Pristocerinae)
}

\author{
Elsa Falières, André Nel
}

\section{- To cite this version:}

Elsa Falières, André Nel. First fossil of the extant flat wasp genus Dissomphalus Ashmead, 1893 (Hymenoptera: Bethylidae: Pristocerinae). Zoosystema, 2020, 42 (15), pp.207-213. 10.5252/zoosystema2020v42a15 . hal-02877190

\section{HAL Id: hal-02877190 \\ https://hal.sorbonne-universite.fr/hal-02877190}

Submitted on 22 Jun 2020

HAL is a multi-disciplinary open access archive for the deposit and dissemination of scientific research documents, whether they are published or not. The documents may come from teaching and research institutions in France or abroad, or from public or private research centers.
L'archive ouverte pluridisciplinaire HAL, est destinée au dépôt et à la diffusion de documents scientifiques de niveau recherche, publiés ou non, émanant des établissements d'enseignement et de recherche français ou étrangers, des laboratoires publics ou privés. 
First fossil of the extant flat wasp genus Dissomphalus (Hymenoptera: Bethylidae: Pristocerinae)

\title{
Elsa FALIERES
}

Andre NEL

Institut de Systématique, Évolution, Biodiversité, ISYEB - UMR 7205 - CNRS, MNHN, UPMC, EPHE, Muséum national d'Histoire naturelle, Sorbonne Universités, Université des Antilles, 57 rue Cuvier, CP 50, Entomologie, F-75005, Paris, France, efalieres@gmail.com, anel@mnhn.fr

\begin{abstract}
Dissomphalus schubnelli sp. nov., first fossil of the extant pristocerine genus Dissomphalus, is described from the Earliest Eocene amber of Oise (France). This genus comprises 424 extant species distributed worldwide (except Antarctica). Dissomphalus schubnelli is the third described Pristocerinae from Oise amber, showing that this subfamily was probably already very diverse at that time.
\end{abstract}

\section{RÉSUMÉ}

Dissomphalus schubnelli sp. nov., premier fossile du genre actuel Dissomphalus de la sousfamille Pristocerinae, est décrit dans l'ambre de l'Éocène basal de l'Oise (France). Ce genre comprend 424 espèces actuelles réparties dans le monde entier (sauf l'Antarctique). Dissomphalus schubnelli est le troisième Pristocerinae décrit de l'ambre de l'Oise, ce qui montre que cette sous-famille était probablement déjà très diversifiée à cette époque.

\section{KEY WORDS}


Insecta

earliest Eocene

sp. nov.

amber

France

\section{MOTS CLES}

Insecta

Eocène basal

sp. nov.

ambre

France

\section{INTRODUCTION}

Bethylidae are frequently found in Cenozoic amber (Azevedo et al. 2018), especially in the earliest Eocene Oise amber of France. We have already recorded one Bethylinae (Eupsenella eocenica De Ploëg \& Nel, 2004), three Epyrinae (Elektroepyris magnificus Perrichot \& Nel, 2008, Chlorepyris gallicus (Perrichot \& Nel, 2008), and Epyris moulyi Falières \& Nel, 2018), one Scleroderminae Paleoscleroderma lamarrei Falières \& Nel, 2019, two Pristocerinae (Pristocera alaini Falières and Nel, 2019, Eopristocera bilobata Falières \& Nel, 2019), and one Protopristocerinae (De Ploëg \& Nel 2004; Perrichot \& Nel, 2008; Falières \& Nel 2019, in press, submitted). Thus this hymenopteran family of parasitoids was already well established and diverse in the Paleogene. Here we describe the first representative in this amber of the pristocerine extant genus Dissomphalus Ashmead, 1893. 


\section{MATERIAL AND METHODS}

The fossil was embedded in a small clear piece of amber. It has been prepared using a diamond disk, examined using a Nikon binocular microscope SMZ 1500. Photographs have been taken with an Amscope camera MU900, and the images treated with Adobe Photoshop Element 12.

The nomenclature and classification follow Terayama (2006) and Azevedo et al. (2018). Main measurements and indices used are as follow: length of forewing (LFW); length of head (LH); width of head (WH); width of frons (WF); height of eye (HE); ocello-ocular line (OOL); width of ocellar triangle (WOT); diameter of anterior ocellus (DAO); vertex-ocular line (VOL). The nomenclature of integument sculpture follows Harris (1979).

\section{SYSTEMATIC PALEONTOLOGY}

Class INSECTA Linnaeus, 1758

Order HYMENOPTERA Linnaeus, 1758

Family BETHYLIDAE Haliday, 1840

Subfamily PRISTOCERINAE Mocsáry, 1881

Genus Dissomphalus Ashmead, 1893

Dissomphalus schubnelli sp. nov.

(Figs 1-5)

HoLOTYPE. MNHN.F.A71308 (PA 16948), male, stored in the collections of the Muséum National d'Histoire Naturelle, Paris, France.

TYPE STRATA. Lowermost Eocene, Sparnacian, level MP7 of the mammal fauna of Dormaal. TYPE LOCALITY. Le Quesnoy, Chevrière, region of Creil, Oise department, France.

ETYMOLOGY. Named after the entomologist Mr. Thomas Schubnell, student of the second author. 
DiAGNOSIS. Hypopygium posteriorly triangular, outer median surface flat; clypeus wholly prominent forward, median lobe not well-outlined; dorsal pronotal area short; notauli welldeveloped and complete; metasomal tergum II longer than I; metasomal tergum II without posterolateral margin strongly incurved; tergal process with pair of dark round pits; no tergal process on tergum III; vein Rs\&M of forewing rather oblique.

DESCRIPTION. Male; body $1.25 \mathrm{~mm}$ long, not depressed, not strongly foveolate; LFW $0.98 \mathrm{~mm}$; head and mesosoma black; metasoma castaneous lightly iridescent, legs castaneous, antenna castaneous; wings hyaline.

Head smooth, not roughly sculptured; mandible with five apical teeth; five maxillary palpomeres, two or three hardly visible labial palpomeres; no spine on gena; clypeus wholly prominent forward, median lobe not well-outlined; antenna rather long, reaching mid part of metapectal-propodeal complex; 11 flagellomeres, cylindrical but basally narrowed; scape: 0.08 mm long x $0.04 \mathrm{~mm}$ wide, pedicel: $0.05 \times 0.03 \mathrm{~mm}, \mathrm{~F} 1: 0.05 \times 0.03 \mathrm{~mm}, \mathrm{~F} 2: 0.06 \times 0.03 \mathrm{~mm}$, F3: $0.06 \times 0.04 \mathrm{~mm}, \mathrm{~F} 4: 0.07 \times 0.03 \mathrm{~mm}, \mathrm{~F} 5: 0.05 \times 0.04 \mathrm{~mm}, \mathrm{~F} 6: 0.06 \times 0.04 \mathrm{~mm}, \mathrm{~F} 7: 0.05 \times$ $0.04 \mathrm{~mm}, \mathrm{~F} 8: 0.05 \times 0.04 \mathrm{~mm}, \mathrm{~F} 9: 0.05 \times 0.04 \mathrm{~mm}, \mathrm{~F} 10: 0.04$ x $0.04 \mathrm{~mm}, \mathrm{~F} 11: 0.08$ x $0.04 \mathrm{~mm}$; frons with numerous setae; dorsal part occipital carina present; eye glabrous; WH 0.28 mm; LH $0.34 \mathrm{~mm}$; OOL 0.14; ocellar triangle equilateral.

Mesosoma: dorsum smooth, not roughly sculptured but punctured; pronotum with anterior margin of disc apparently not carinate; dorsal pronotal area short; notauli well-developed and complete; parapsidal signum absent or strongly reduced; mesoscuto-mesoscutellar suture opened in its median part, with two lateral foveae, each linked to the suture by thin line; metanotum with medium region narrower than lateral regions, developed medially and overlapping mesoscutellum posteriorly; metanotal groove without foveae but with setae; metapectal-propodeal complex smooth with posterior carina and very small postero-lateral spines. 
Forewing covered with microtricha and bordered with small setae; anterior border not angularly incurved anterior to pterostigma; costal vein present; vein 2 r-rs\&Rs vein long and as strong as other veins but not closing cell 2R1; strong vein cu-a more distal and vein $\mathrm{M}$; a vein $\mathrm{Cu}$ and a vein A distal to cu-a; cells $\mathrm{R}, 1 \mathrm{Cu}, 2 \mathrm{Cu}$ closed; cells $1 \mathrm{R} 1$ and $1 \mathrm{M}$ absent; no basal stub of $\mathrm{Rs}+\mathrm{M}$; poststigmal abscissa of R1 very short, ghost FRR (first recurrent vein) and SMC cell (submarginal cell) present.

Metasoma: short petiole; seven tergites, convex, partly covering sternites; posterolateral margin of tergite II without posterolateral margin strongly incurved, with pair of lateral pits; tergite III without tergal process; hypopygium entire, posteriorly triangular.

Length of tergites: T1 about $0.05 \mathrm{~mm}, \mathrm{~T} 20.12 \mathrm{~mm}$, T3 $0.07 \mathrm{~mm}, \mathrm{~T} 40.08 \mathrm{~mm}$, T5 $0.07 \mathrm{~mm}, \mathrm{~T} 6$ $0.06 \mathrm{~mm}, \mathrm{~T} 70.05 \mathrm{~mm}$.

\section{DISCUSSION}

Following the key to subfamilies of Azevedo et al. (2018), Dissomphalus schubnelli sp. nov. falls in Pristocerinae because of the following characters: male fully winged; forewing with Rs $+\mathrm{M}$ vein absent; metanotum developed medially and overlapping mesoscutellum posteriorly. After the key to pristocerine genera, it would fall near the genus Dissomphalus because of the body size smaller than $15 \mathrm{~mm}$; hypopygium not deeply divided into two lobes, posterior margin not incurved, with outer median surface flat; clypeus wholly prominent forward, with median lobe not well-outlined; dorsal pronotal area short; notauli well-developed and complete; metasomal tergum II longer than I; metasomal tergum II without posterolateral margin strongly incurved; with tergal process as a pair of dark round pits; no tergal process on tergum III. Benoit (1956), Terayama (1996) and Azevedo (2014) revised the genus Trichiscus Benoit, 1956, closely related to Dissomphalus, indicating that the former has tergal processes in the metasomal segment III, consisting of some paralleled rows of setae placed on anterior third of 
lateral surface. These structures are clearly absent in Dissomphalus schubnelli. Thus we tentatively attribute this fossil to the genus Dissomphalus.

At least the Thai, African, and Neotropical species of Dissomphalus have a small median concavity on the hypopygium, unlike Dissomphalus schubnelli (Azevedo 1999, 2003, 2010; Mugrabi \& Azevedo 2013). Nevertheless it was not possible to compare Dissomphalus schubnelli with the extant species because the necessary male genitalia were not visible. Dissomphalus schubnelli is likely to be a new species because of its antiquity (53 Myrs old), while no extant insect is known to have lived more than 10 Myrs. The vein Rs\&M of the forewing is not so vertical in Dissomphalus schubnelli as usual for the extant Dissomphalus spp. (Azevedo et al., 2018: fig. 27F), which could be a significant difference with the extant representatives of the genus. Unfortunately, this structure is generally not figured even in the most recent papers.

\section{CONCLUSION}

Dissomphalus schubnelli is the first fossil record of this genus and the third Pristocerinae from the Oise amber, suggesting that this subfamily was already very diverse during the earliest Eocene. Dissomphalus is a very large genus, distributed over all the continents. There is very few information on the biology of the Dissomphalus, Azevedo et al. (2018) indicated that some species have been recorded on Bruchidae (Coleoptera), Micromalthidae (Coleoptera) and Cecidomyiidae (Diptera). A Micromalthidae and several Cecidomyiidae are described from the Oise amber (Nel \& Prokop 2006; Kirejtshuk et al. 2010), both families potential hosts for Dissomphalus schubnelli.

\section{Acknowledgements}


We thank two anonymous referees for their useful comments on the first version of this paper.

We thank the Lafarge-Granulat company for help with the fossil sampling and the LangloisMeurinne family for the authorization of working on their property.

\section{REFERENCES}

AzEvedo, C.O. 1999.- Revision of the Neotropical Dissomphalus Ashmead, 1893 (Hymenoptera, Bethylidae) with median tergal processes. Arquivos de Zoologia 35: 301-394. AzEvedo, C.O. 2003.- Synopsis of the Neotropical Dissomphalus (Hymenoptera, Bethylidae). Zootaxa 338: 1-74.

AzEvedo, C.O. 2010.- Review of Afrotropical Dissomphalus (Hymenoptera, Bethylidae), with emphasis on genitalia. Journal of Afrotropical Zoology 6: 9-22.

Azevedo, C.O., Alencar, I.D.C.C., Ramos, M.S., Barbosa, D.N., Colombo, W.D., Juan M. VARGAS R., J.M. AND LiM, J. 2018.- Global guide of the flat wasps (Hymenoptera, Bethylidae. Zootaxa 4489: 1-294.

BENOIT, P.L.G. 1956.- Contributions à l'étude de la faune entomologique du Ruanda-Urindi. (Mission P. Basilewsky 1953). CXII. Hymenoptera Bethylidae. Annales du Musée Royal du Congo Belge, Sciences Zoologiques (Série 8) 51: 560-564.

DE PloËG, G. \& NeL, A. 2004.- A new bethylid wasp from the Lowermost Eocene amber of France (Hymenoptera: Bethylidae: Bethylinae). Geologica Acta 2: 75-82.

FALIÈRES, E. \& NEL, A. 2018.- The oldest representative of the extant genus Epyris in the Lowermost Eocene amber of France (Hymenoptera: Bethylidae: Epyrinae). Palaeoentomology 1: $32-36$.

FALIÈRES, E. \& NEL, A. 2019.- A new bethylid wasp from the Lowermost Eocene Oise amber (France) (Insecta: Hymenoptera). Palaeoentomology 2: 211-214. 
FAliÈres, E. \& Nel, A. 2019.- The first sclerodermine and pristocerine flat wasps in Lowermost Eocene amber of France (Hymenoptera: Bethylidae). CR Palevol in press.

FALIÈRES, E. \& NEL, A. 2019.- The oldest 'accurate' representative of the extinct flat wasp subfamily Protopristocerinae (Insecta: Hymenoptera: Bethylidae). Alcheringa submitted.

HARRIS, R.A. 1979.- The glossary of surface scupturing. Occasional Papers in Entomology, California Department of Food and Agriculture Laboratory Services, supplement 28: 1-31.

KirejtshuK, A.G., Nel, A. \& Collomb, F.-M. 2010.- New Archostemata (Insecta, Coleoptera) from the French Paleocene and Early Eocene. Annales de la Société Entomologique de France (N.S.) 46: 216-227.

Nel, A. \& Prokop, J. 2006.- New fossil gall midges from the earliest Eocene French amber (Diptera: Cecidomyiidae). Geodiversitas 28: 37-54.

Perrichot, V. \& NeL, A., 2008.- Eocene bethylid wasps from French amber (Hymenoptera: Bethylidae). Neues Jahrbuch für Geologie und Paläontologie, Abhandlungen 248: 91-11.

Terayama, M. 1996.- The phylogeny of the bethylid wasp subfamily Pristocerinae (Hymenoptera: Bethylidae). Japanese journal of Entomology 64: 587-601.

Terayama, M. 2006.- The Insects of Japan. Vol. 1. Bethylidae (Hymenoptera). Touka Shobo Co. Ltd., Fukuoka, Entomological Society of Japan: 1-319.

FIG. 1. Dissomphalus schubnelli sp. nov., holotype MNHN.F.A71308, habitus: A, above; B, below; $\mathbf{C}$, left side. Scale bars represent $1 \mathrm{~mm}$.

FIG. 2. Dissomphalus schubnelli sp. nov., holotype MNHN.F.A71308, A, wings; B, metasoma left view; C, metasoma right view, arrow tergal process. Scale bars: A, B $0.5 \mathrm{~mm}$; C $0.2 \mathrm{~mm}$. FIG. 3. Dissomphalus schubnelli sp. nov., holotype MNHN.F.A71308: A, head and anterior part of mesosoma, arrow metanotum; B, head, arrow clypeus. Scale bars: A $0.4 \mathrm{~mm}$; B $0.2 \mathrm{~mm}$. 
FIG. 4. Dissomphalus schubnelli sp. nov., holotype MNHN.F.A71308, mandibles: A, front view; B, side view. Scale bars: $0.08 \mathrm{~mm}$.

FIG. 5. Dissomphalus schubnelli sp. nov., holotype MNHN.F.A71308. Hypopygium. Scale bar: $0.05 \mathrm{~mm}$. 


\section{A}

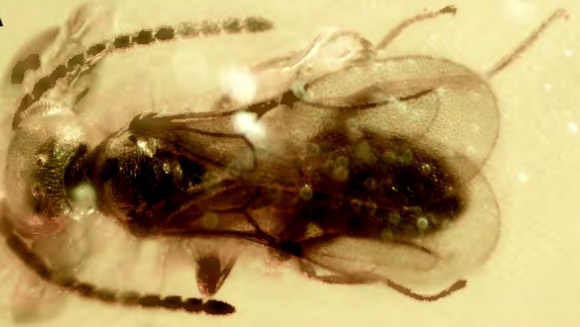

B
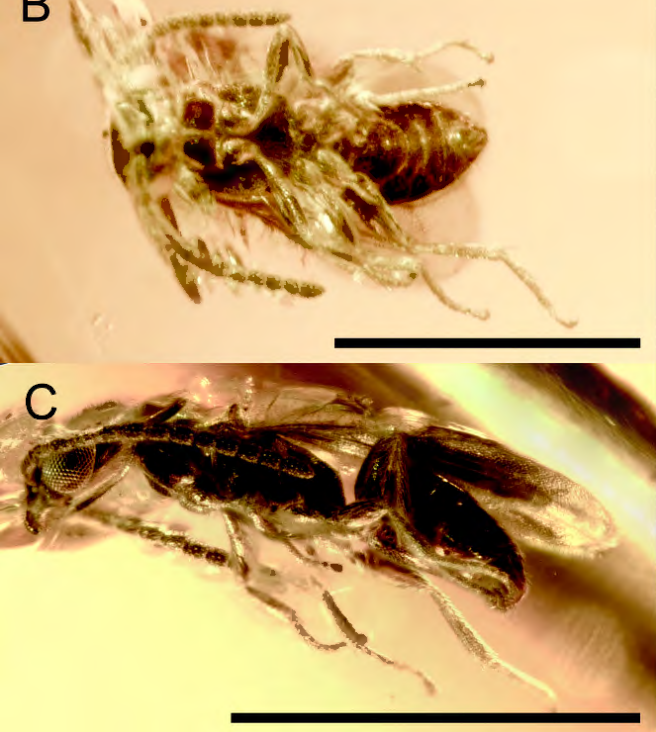


\section{$A$}

5.7. $5 x+6$

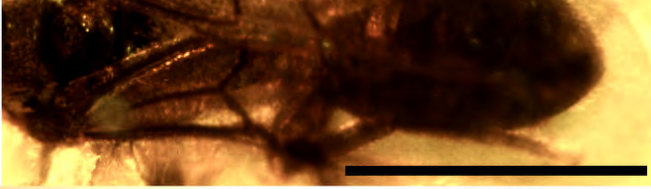

B

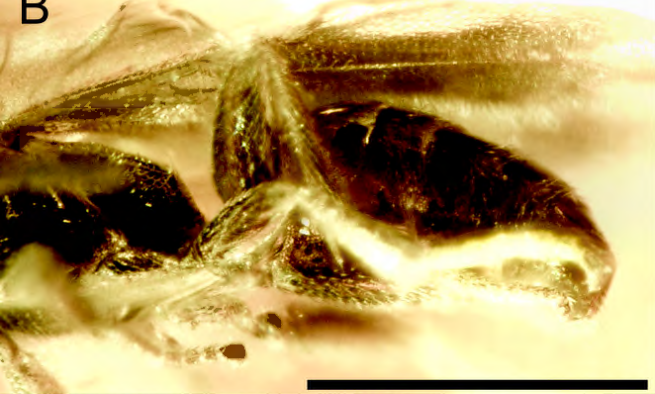

\section{C}

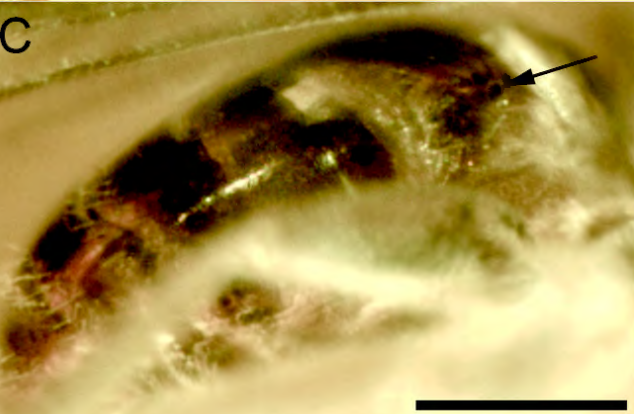


A

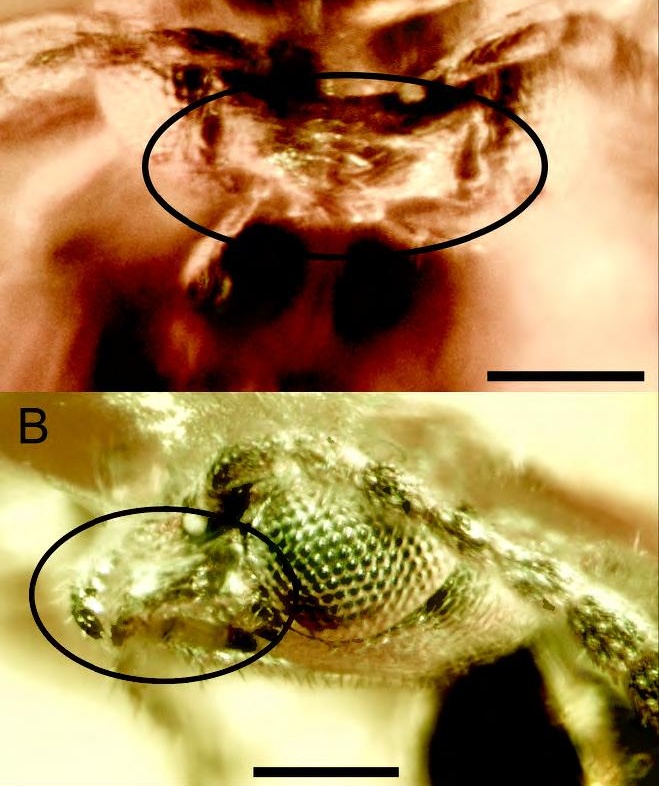



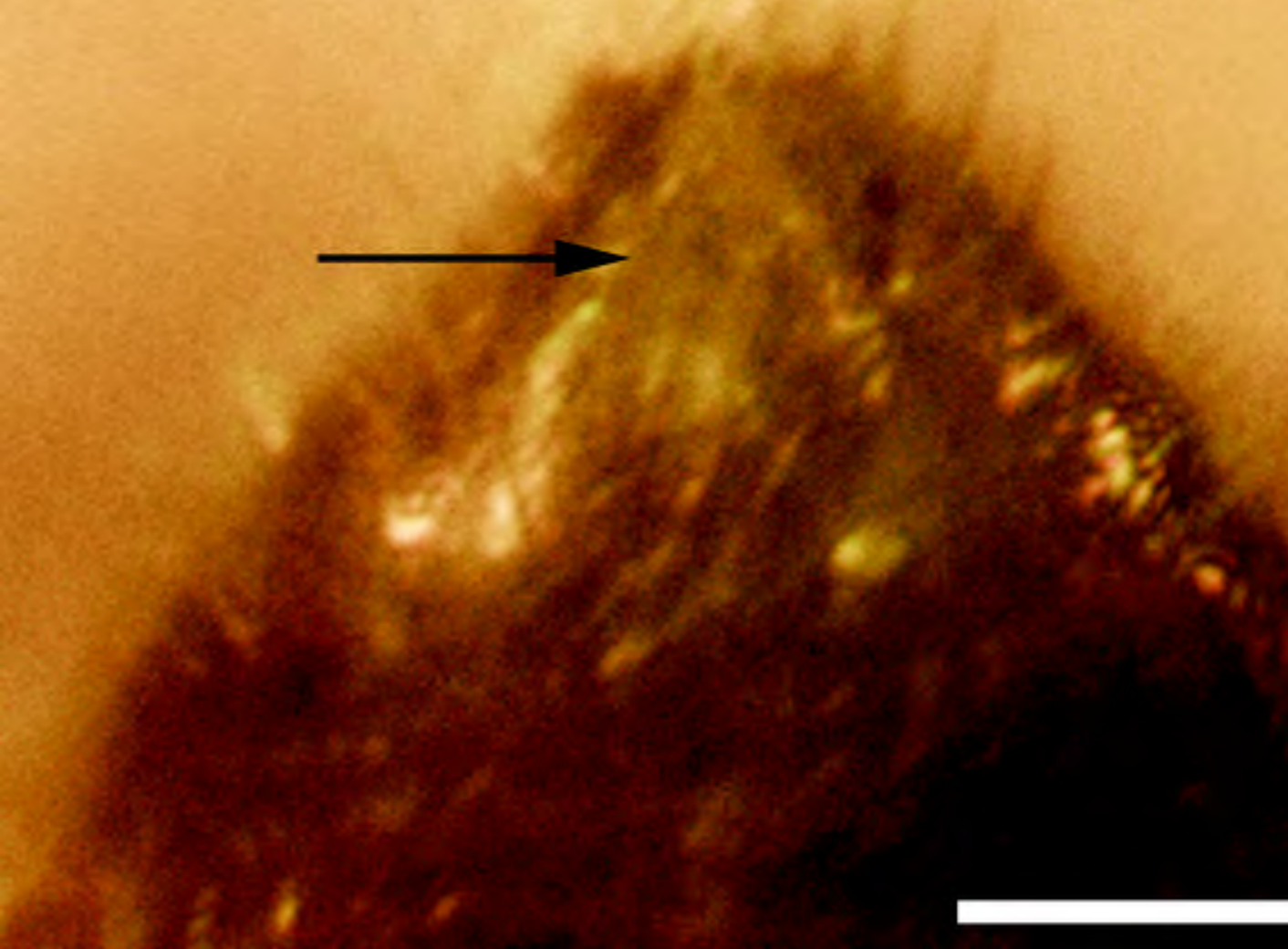

6.8.

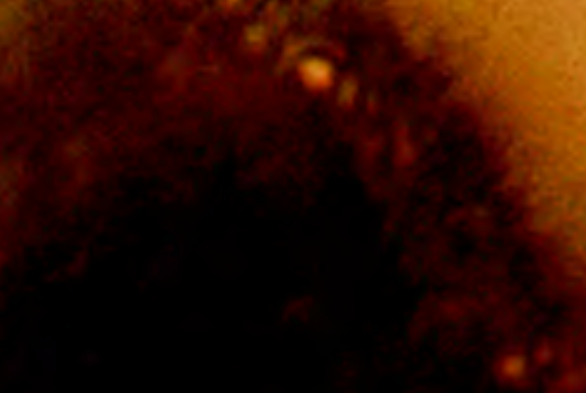

